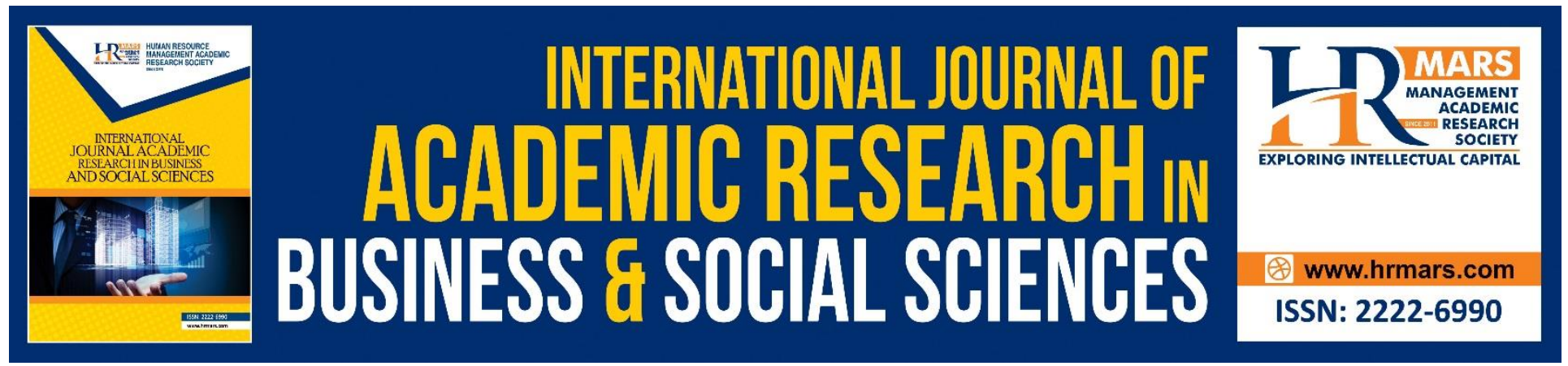

\title{
Implementation of Scenography Elements in the Production of' Creative Arts among Upper Secondary Students through Theatrical Production in the Malaysia Arts School of Johor
}

\section{Zolkipli Abdullah, Muhammad Fazli Taib Saerani, Syarul Azlina Sikandar}

To Link this Article: http://dx.doi.org/10.6007/IJARBSS/v9-i3/5796

DOI: $10.6007 /$ IJARBSS/v9-i3/5796

Received: 30 Jan 2019, Revised: 10 Feb 2019, Accepted: 02 March 2019

Published Online: 30 March 2019

In-Text Citation: (Abdullah, Saerani, \& Sikandar, 2019)

To Cite this Article: Abdullah, Z., Saerani, M. F. T., \& Sikandar, S. A. (2019). Implementation of Scenography Elements in the Production of' Creative Arts among Upper Secondary Students through Theatrical Production in the Malaysia Arts School of Johor. International Journal Academic Research Business and Social Sciences, 9(3), 1291-1297.

\section{Copyright: (C) 2019 The Author(s)}

Published by Human Resource Management Academic Research Society (www.hrmars.com)

This article is published under the Creative Commons Attribution (CC BY 4.0) license. Anyone may reproduce, distribute, translate and create derivative works of this article (for both commercial and non-commercial purposes), subject to full attribution to the original publication and authors. The full terms of this license may be seen

at: http://creativecommons.org/licences/by/4.0/legalcode

Vol. 9, No. 3, 2019, Pg. 1291 - 1297 


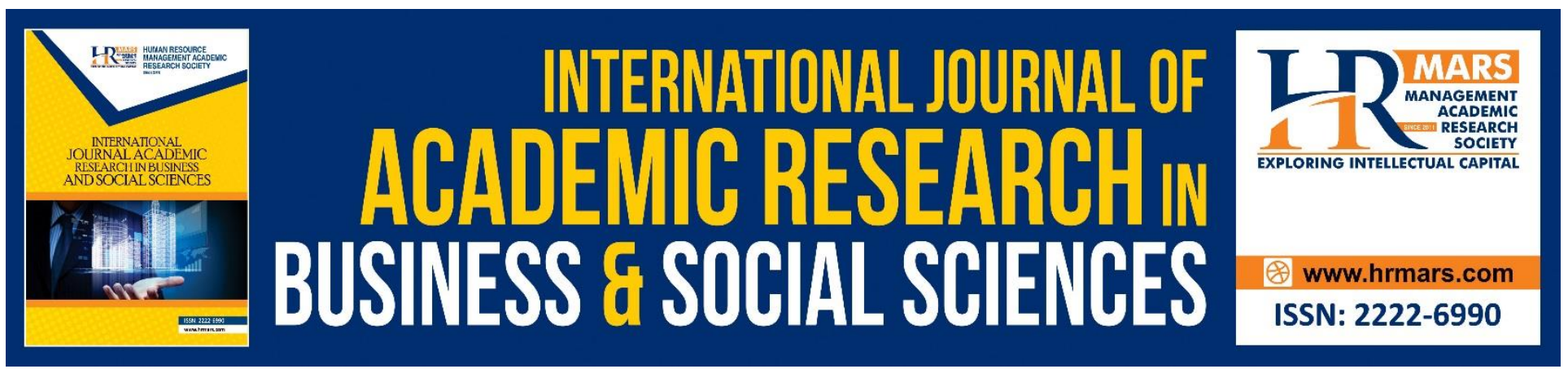

\title{
Implementation of Scenography Elements in the Production of' Creative Arts among Upper Secondary Students through Theatrical Production in the Malaysia Arts School of Johor.
}

\author{
Zolkipli Abdullah \\ Faculty of Music and Performing Arts, Sultan Idris Education University, Malaysia \\ Muhammad Fazli Taib Saerani \\ Faculty of Music and Performing Arts, Sultan Idris Education University, Malaysia \\ Syarul Azlina Sikandar \\ Faculty of Music and Performing Arts, Sultan Idris Education University, Malaysia
}

\begin{abstract}
The implementation of scenography in the creation of artistic and creative works are in correlation are also important components in theatrical process of a theatre production. This is because components of scenography puts together elements of visual design and creative ideas in abstract, realistic and experimental forms based on the concepts and themes of the manuscripts that will be staged. The study therefore demonstrates the role of scenography in producing a theater production at the Malaysian Art School of Johor which is effective with the application of teaching and learning patterns that focus on building creative and innovative thinking skills through exploration activities to enhance the ability to create and produce quality ideas. The results of this study show the significance of scenography exploration through appropriate approaches to ensure the understanding of the processing of the scenography element amongst instructors and students in the early stages of the arts science, basic principles of design and technical skills in a theater production.
\end{abstract}

Introduction

The emphasis on creative and innovative human capital development in order to meet the requirements of the nation in the 21st century has been stated in the Malaysian Education Blueprint. The implementation of creative and innovative elements in Malaysian Art Schools will accelerate the country's transformation agenda which goes hand in hand to ensure that this process is implemented 
through teaching and learning in school. The learning of Scenography generally aims to build up students' creative ability in creating artistic work through scenography. Scenography is closely related to visual arts, in other words, visual literacy, which includes the ability to use visual language to read and appreciate visual images. Scenography is one of the key components in a theatrical process, especially one which contributes to the unity in the creation of a design, the ideas of its employees and production experts. Its teaching and learning pattern involves the diverse creative methods made to ensure students are exposed to forms beyond their field of experience, especially in the arts and theater works in practice.

Scenography is closely related to visual arts; reading visual language is a key instrument in producing onstage visuals. Through this visualization process, scenographers require a variety of methods to visual observation such as photography, reality and viewing experiences, (Pamela, 2003). The complicated process of visually interpreting script requires deep and complex imagination and creativity, since the visual existence presented onstage needs to accurately represent the settings presented in script as well as character traits. Most importantly the visuals need to be acceptable by logic and can be interpreted well not only the audience but members of the production as well. The development of creativity and innovation amongst students in Malaysian Art Schools, particularly in the teaching and learning of scenography aims to shape exemplary individuals who are creative, innovative and capable producing quality ideas and inventions thus enabling Malaysian Art School students to compete with others on an internation scale.

\section{Importance and Benefits in the Research of Implementation of Scenography in Creative Production among Students through Theatrical Production}

The problem statement of this research is based upon the researcher's concern in observing the theatrical production in the final presentation in which is an assessment for Upper Secondary Students of Malaysia Art School, Johor in which the element of scenography and production design is deemed not asimporant in comparison to acting and directing. Assumptions such as these are actually wrong in the sense that in the current era, scenography has been regarded as a very important communication medium onstage contributing to the formation of a unition within a theater production in establishing artistic values of acting and direction.

Therefore, the researches focuses on the potential and suitable forms to ensure the understanding of the process of design in the elements of scenography amongst instructors and students who should gain these exposure at an early stage about the background knowledge of the Arts, basic principles in design as well as knowledge of technical skills focused in the organization involved in the a theatrical production. The importance of this design process will be focused towards groups of students who are designers of the young generation who lack experience in understanding the techniques in involved in stage design that involve the collaboration of various parties. Other than that, the element of developing creativity and talent has to be emphasized by taking the step of cultivating the culture of creativity and innovation at the school level to develop individuals who are holistic, knowledgeable, creative, critical and innovative through improvements made in the curriculum of the Arts.

Thus, other than ensuring the introduction of the design process of scenography is not left behind, the quality of design will also be something that should be looked at with pride. Education in fine arts 
and performing arts at the upper secondary level of the Malaysian Arts School should be refined to meet the needs of the performing arts, through proactive measures such implementing transformation and enhancement in terms of an innovative curriculum structure by emphasizing creativity and innovation skills.

The importance and benefits of this research is being able to identify important aspects that has to be given attention in the creation of sceno graphic elements in theatrical production which the use of artistic elements and principles of design at every stage which will contribute to the effectiveness in the process of learning and teaching in a theatrical production that will be performed and contains artistic elements of scenography. Relatively, this will ensure the understanding of the importance of scenographic elements in terms of upper secondary theatrical production in Malaysia Arts School of Johor.

In addition, it gives exposure and increases comprehension towards the importance of scenographic elements amongst instructors involved in the theatrical production process in the upper secondary level. Knowledge sharing which can be used by the instructors and production team helps to create an effective design process and clarity in the scenographic visual image, in cultivating students' talent and potential in an integrated manner for a theatrical production that possesses artistic elements. Also, to produce work procedure for the line of instructors which includes the importance of conserving the application of scenographic elements.

\section{Exploration of Scenographic Design in Creative Production of Students in Theatrical Production} Scenography design exploration focuses on building creative thinking and innovative thinking skills through exploration activities. Exploration activities such as text studies, visual studies, the study of space and sound as well as special effects are aimed at obtaining a variety of information to reveal the ideas and concepts of scenography.

The study of texts is aimed at obtaining information such as the background of the society, the background and the time, the social status and the socio-cultural information. The visual survey is aimed at obtaining appropriate image requirements information based on scenography ideas and concepts. The findings from the study of space can be used to design the layout of the actor's movements as well as the use of sets and props according to the suitability of the play's space. The study of the suitability of sound and special effects are designed to provide a list and a collection of sounds and special effects which appropriate to use. Apart from that, exploration activities of various forms of media such as digital media, photography, video, magazines and newspapers also help to obtain information and ideas in creating the scenographic design.

\section{Scenographic Creation in Students' Creative Production through Theater Production}

The things that are taken into consideration by a scenographer are the aspects of the script such as the number of scenes, the setting, the time setting and the historical background. Other than that, design aspects such as materials and media used in design and build sets, the size and quantity requirements of a design and set, a stage environment that will have aesthetic impact between the set and the prop, the elements of which can bring about admiration and awe, the aspect of floor plan space and sound effects and music in the particular play. All these scenographic elements and design 
principles are important for a scenographic designer to be mindful of when planning the idea of the scenographic stage design which all contributes to the goal of an effective show.

According to Kennedy, (1996) the importance of scenography in learning theatrical production is deemed equivalent to the text when dialogue creates the art of conversation and behavior on stage, scenography creates its visuals. The scenography element is a reminder that the words from a text are not enough to perfectly describe the intended meaning. According to Pamela (2003), scenographic design in a play production are visual adaptations or representations through texts; implemented through sets and costumes and are equipped with lighting aspects designed in support of actors through dialogue and movement in a play. This process involves visuals and is influenced by the dramatization of the manuscript. The script's dramaturgy needs to be well-grounded by artistic directors and designers in production, both of these important components should have the same visual language for the smooth flow of performance during a show.

In individual development from the creative aspect of design, it is important to note that it is viewed as important because it relates to the development of students' cognitive style in scenographic learning. Therefore, an identified important element may be the fact of influence towards the development of creativity amongst students through their cognitive style that involves the visual sense. According to the study of Reid (2004), creative thinking skills in solving a problem are needed by every student who wants to get better quality ideas. The creative cognitive style is an important aspect as it sees how an individual can think creatively by using innovative ways of producing quality and creative ideas for solving a particular problem in the design.

Sofia Pantouvaki, mentioned that the synthesis of the theoretical element of scenography in theatre production will provide explicit information to the audience about the place and the time, preparing a specific drama setting that touches on the social and historical context, otherwise it treats the rest of the artistic and aesthetic insights and the publishing team if historical references have been replaced by contemporary or more technological approaches. (Pantouvaki, 2010). A scenographer should think like a director, he must care about how his designs can be used and posses dramatic values on stage. Scenography is not a static image or painting in the play context and stage area but needs to be dynamic, having an impact on dramatic stunts such as the cast on stage. (Kennedy, 1996).

Several academic surveys can be seen using a number of theories to analyze the research that is to be undertaken. The reformation of the national education system should prioritize integrated plans to optimally develop the potential and talent of the generation of students. According to Howard Garder (1983), the potential of a human individual can be attributed to eight (8) categories, through the Multiple Intelligence Theory that he describes, Garder argues that an individual is able to portray special talents in one or combinations of the following domains: musical-rhythmic, visual-spatial, verbal-linguistic, logical-mathematical, bodily-kinesthetic, interpersonal, intrapersonal and naturalistic. In other words, an individual can be assumed to have at least one potential or a talent in which that particular domain can be further developed. 
The debate about elements in scenography usually uses semiotic theory or aesthetics theory to analyze the elements or the meaning of the visual image displayed. From the scenography aspect, symbolism plays an important role to see a series of insights into the background of human life (Rohidi, 2000). The design process in scenography is an initiative in educating, giving knowledge, proving a space for discussion and the sharing of experiences which can be used as a basic guide in the creation of creative works in field of theater in school.

Through this study, the aspects of theoretical analysis of the researcher use the theory of Pierce. According to Aart van Zoest (1978) taking Pierce's opinion, there are three categories that focus on three levels: Firstness, Secondness and Thirdness. The process of scenography goes through the stages of cognitive and psychomotor aspect, and the production of effective results which will contribute to unity in ensuring the final product meets the requirements in producing a quality play production. The main process of scenography in theatre includes strategies and essences such as information, research, formation and development of ideas, exploration, synthesis and manufacture as well as evaluation.

\section{Conclusion}

The Arts Education Curriculum for the Malaysian Art School of the Secondary Level aims to produce individuals with the knowledge, skills and theatre experience that will in the future, become practitioners and theatre artists in an effort to build a generation of heirs of the Malaysian cultural heritage.

The definition and meaning of the curriculum by Stufflebeam, (1977), states some of the elements or objects involved directly. These objects are students, environments, methods or implementation strategies, achieving revenue expectations and overall engagement. Each object plays a big role in determining the success of the established curriculum. However, the main goal of curriculum development is for the benefit of students. So, problems related to them should be included in the process of discussion and planning as well as the formation of the curriculum. The subject of Scenography encourages students to think, imagine and make interpretations. Teaching methods in this subject should be varied and diversified in order to help students understanding and master a particular concept or skill. In the Scenography Curriculum of Malaysia Arts School, it aims to equip students with the knowledge and skills of scenography to produce creative, innovative and disciplined individuals with positive self-esteem through the work they produce.

In the development of the art curriculum, art disciplines need to be given priority, according to Chapman (1985), three factors need to be emphasized, namely the expression and the selfexpression in art, the artistic heritage and the role of art in society or the environment. Therefore, according to Chapman also, art discipline is considered as an affirmation of the teaching and learning of art in the school, which begins with the focus on student expressions and further develops art skills in various fields.

According to Schwab, (1981), disciplinary structures are very important to educators and education. Efland, (1983), states that when a field of knowledge has good structure and the right methods to 
acquire knowledge, it becomes a strong discipline. "Multi-Discipline" means the combination of different disciplines or other areas of knowledge as a back-up or support for major disciplines. The "Discipline \& Multi-Discipline" curriculum will combine four basic disciplines (aesthetics, artistic creation, art criticism, art history and performing arts) with several other visual arts disciplines in science and technology, multimedia and others.

Students who will receive knowledge disciplines should also prioritise exposure to knowledge of psychology such as cognitive psychology, psychoanalytic, behavioristic and others related to human behavior (students). For example, through imitation. Psychoanalytic theory also shows an emphasis on expressive behavior for a painter and designer.

Meanwhile, the environment is also an important aspect of intellectual development and student behavior. People of diverse and multiracial races in Malaysia as well as their environment also play a role in education. A good curriculum is also very much dependent on the advancement aspect of the environment in a multitude of ways. For example, the current K-economy concept is highly dependent on a conducive environment with modern facilities or infrastructure. Hence, in order to produce this authoritative heir of generations, the transformation of the current national education system should recognize the diversity and unique potential of local students. As Gardner (1983) states, on the need to inculcate the potential and individual talents in an integrated manner, it is the responsibility of all possible stakeholders to realize the aspirations of a developed country which requires a competitive, high-potential and talented human resource.

\section{References}

Barret, M. (1982). Art education: a strategy for course design. London: Heinneman Educational Books.

Chapman, L. H. (1973). Approoach to art in education. New York: Harcourt Brace Jovanovich Publisher.

Gardner, H. (1983). Frames of mind: a theory of multiple intelligences. New York: Basic Books. Mitchell, K. (2008). The director's craft: A handbook for the theatre. USA: Routledge.

Kenneedy, D. (1996). Looking at shakespeare. Campbridge: University Press.

Parker, W. T. (1970). The principles of aesthetics. $\left(2^{\text {nd }}\right.$ ed). New York: Appleto Century Crofts, Inc. Pamela, H. (2009). What is scenography. London: Routledge.

Bujang, R. (2008). Rekabentuk seni. Kuala Lumpur: Universiti Malaya.

Rohidi, T. R. (2000). Kesenian dalam pendekatan kebudayaan. Bandung: STSI Press.

Pantouvaki, S. (2010). Visualising theatre studies: scenography from concept to design realisation mapping minds. Monika Raech: IDP

Van, Z. A. (1979). Semiotiek: Over tekens, hoe ze werken en wat We Er Mee Doen. Baarn: (Terj. Kristiana Wardana).

Vincent, L.B. (2002).The Filmaker's guide to production Design.USA: Allworth Press.

Wagner, T\&K. R. (2006). Change leadership: a practical guide to transforming our schools. SF: Jossey-Bass

Parker, W. O. (2009). Scene design and stage lighting. USA: Wadsworth, Cengage Learning Boston. 